\title{
Indigenous Tourism Policy in Australia: 25 Years of Rhetoric and Economic Rationalism
}

\author{
Michelle Whitford \\ School of Tourism and Leisure Management, University of Queensland, Ipswich \\ 4305, Australia
}

\section{Barry Bell and Mike Watkins}

School of Leisure Studies, Griffith University, Mt Gravatt, 4111 Australia

\begin{abstract}
Successive Australian federal and State governments have produced tourism policies to facilitate the development of Aboriginal and Torres Strait Islander [ATSI] tourism. However, the effectiveness and appropriateness of these policies has been questioned. This paper describes a qualitative study examining federal and Queensland State governments' ATSI tourism policies during the period 1975 to 1999. Three main findings of the study were: (1) ATSI tourism policies are published in an ad hoc manner and appear to be related to a reactive approach by governments to broader ATSI social and economic issues; (2) economic concerns dominate ATSI tourism policies and emphasise the commodification of indigenous tourism; and (3) policies are strongly reflective of an economic-rationalist ideology. The study concludes that the emphasis on economic rationalism assists Australian tourism enterprises to be internationally competitive but may create undesirable consequences for indigenous tourism stakeholders.
\end{abstract}

\section{Introduction}

The diversity of the world's indigenous cultures has ignited the curiosity and imagination of a growing number of people. Aboriginal and Torres Strait Islander [ATSI] tourism is an integral part of Australia's tourism industry (Moore \& Herron, 1997). Australia, as home to one of the world's oldest living cultures, is 'well placed to open the window of opportunity presented by the growing interest in indigenous tourism' (Office of National Tourism, 1998a). Underpinning ATSI tourism have been the attempts by various Australian governments to initiate policies in the form of plans, reports, strategies and discussion papers aimed at facilitating the growth of this sector of the tourism industry. The purpose of this paper is to examine ATSI tourism policy developed by successive federal and Queensland state governments during the period 1975 to 1999 . $^{1}$

Whilst responsibility for ATSI tourism policy rests primarily with the federal government, various Australian states have also been actively involved in the development of ATSI tourism (see Zeppel, 1998a, 1999). For example, Queensland is visited by $74 \%$ of international tourists to Australia and the majority of these travellers express an interest in experiencing ATSI cultures (Office of National Tourism, 1999). This demand has resulted in a number of relevant policies being developed by the Queensland State government to facilitate the growth of ATSI tourism such as Framework for the Future (Department of Tour- 
ism, Small Business and Industry, 1997a) and the Queensland Ecotourism Plan (Department of Tourism, Small Business and Industry, 1997b).

The development of ATSI tourism policies, at both federal and State levels has been questioned by authors such as Altman (1989), Finlayson (1993) and Hollinshead (1996) in terms of their appropriateness to ATSI people. According to Pigram (1993) the process of developing such policies seems to have occurred on an ad hoc basis culminating in a lack of effective policy (also see Hall et al., 1997). Authors including Altman and Finlayson (1992) and Finlayson (1993) in particular, have noted the apparent interrelationships between the broader cultural context and the effectiveness, consequences and impacts of various ATSI tourism policies. The focus of government activity is public policy and such policy is a consequence of the political environment influenced, among other things, by values and ideologies (Hall et al., 1997). Indeed, any government policy or theme is underpinned, to some degree, by the political party's ideological platform (Finlayson, 1993).

Thus, the three objectives of this study were: (1) to catalogue the distribution, authorship and substance (i.e. level) of policy developed in relation to ATSI tourism; (2) to ascertain which aspects of broader social, economic, political and ecological environments are reflected in ATSI tourism policies; and (3) to examine the political ideologies underpinning these policies. Before proceeding to describe the methods and results of the study it is necessary to present an overview of ATSI tourism and to describe the key events in the history of Australian government involvement in ATSI tourism policy since 1975 in order to provide a context for an empirical analysis of ATSI tourism policy.

\section{Aboriginal and Torres Strait Islander Tourism}

Indigenous tourism refers to 'activity in which indigenous people are directly involved whether in control and or by having their culture serve as the essence of the attraction' (Butler \& Hinch, 1996: 9). Contemporary history reveals that both the Australian tourism industry and indigenous Australians became aware of tourist interest in ATSI culture during the mid 1900s. Hollinshead (1996: 312) maintained that this interest in 'the heritage of indigenous Australia is now being moved into direct focus across the globe.' The diverse array of experiences offered to tourists ranges from a bush-walk taking a few hours, or a five-day safari (Pitt cited in Office of Northern Development, 1993), to 'living with Aboriginal or Island family groups in their own country for a short period (e.g. 310 days), or guided tours to art and other sites of significance, attending live performances (e.g. dance, drama, music), to appreciating visual arts in state museums and galleries or their commercial counterparts' (Fourmile, 1992). However, at the core of indigenous involvement in the tourism industry is the production of arts and crafts for sale to tourists. The Office of National Tourism, (1999) estimated the worth of the indigenous arts and crafts industry to be approximately $\$ 200$ million per annum, and $48 \%$ of international visitors showed interest in seeing and learning about Aboriginal art and culture (South Australian Tourist Commission, 1998).

The stakeholders of indigenous tourism include domestic and international visitors, ATSI people, industry, special interest organisations and government. 
While domestic visitors represented a minor market for ATSI tourism, Tourism Queensland stated 74\% of international travellers to Australia visit Queensland (Queensland Tourism and Travel Corporation, 1999) and 50\% of all international visitors to Australia expressed an interest in experiencing Aboriginal and Torres Strait Islander cultures (Office of National Tourism, 1999). This indicates the importance of international tourists within the stakeholder groups of ATSI tourism.

ATSI communities are another important stakeholder group and while there were 95,430 ATSI people in Queensland in 1996 (Queensland Government Statistics, 1999), the current level of employment of ATSI people in the tourism industry is low (Office of National Tourism, 1999). However, those ATSI people involved in tourism ventures operate either as individual enterprises, as joint ventures between indigenous and non-indigenous people or as community enterprises (Office of Northern Development, 1993). Tourism operations owned by indigenous Australians are estimated to be worth around an extra \$20 million to $\$ 30$ million per annum (Office of National Tourism, 1998b). Successful tourism ventures are displayed in the Office of National Tourism (1999) publication, $A$ Talent for Tourism. These successful ATSI tourism enterprises include Bangarra Dance Theatre in Sydney, Desert Tracks in Alice Springs, Dreamtime Cultural Centre in Rockhampton and Tjapukai Dance Theatre in Cairns (see Zeppel, $1998 b)$. The success of such enterprises is dependent to varying degrees on government policy. The following section will trace the development of federal and Queensland state government policies that have facilitated the growth of ATSI tourism.

\section{A History of Australian Federal Government Involvement in ATSI Tourism}

As early as 1965, indigenous involvement in the tourism industry was specifically recommended in the first government-initiated major national report on the tourism industry by Harris, Kerr and Foster titled, Australia's Travel and Tourism Industry. Several years later, in 1971, the Northern Territory demonstrated a proactive approach to ATSI tourism in the Northern Territory Newsletter (1971), which announced new training courses for young Aboriginal women to become 'efficient' tourist guides, bus hostesses or kiosk attendants.

In 1973, the Labor Party, led by Gough Whitlam, won the federal government election and created a new Department of Tourism and Recreation. Forell (1994) noted that during the Whitlam era of the early 1970s, the doctrine of equal opportunity for all Australians was paramount. Consequently, the Whitlam government strove for social progress, economic justice, racial and sexual equality and Aboriginal rights. The Whitlam government had only two years to follow and implement these traditional Labor Party platform ideals. The year 1975 marked the beginning of the Liberal federal government led by Malcolm Fraser and a commitment to the idea that the public sector was unproductive and big government was the source of inflation (Maddox, 1991). This sentiment is indicative of a laissez-faire political ideology that honours the virtues of free enterprise and presupposes that all are able to compete on equal terms (Manning, 1976). 
Under the Fraser government, the Department of Tourism and Recreation was abolished and tourism became a branch of the newly created Department of Industry and Commerce. The future of tourism was in the hands of a Select Committee on Tourism that concluded tourism 'is of considerable economic significance and deserves greater recognition' (Craik, 1991a). Approximately 10 years later this recognition was reinforced in The Report of the Australian Government Inquiry into Tourism (Commonwealth of Australia, 1986) which, among other things, identified the untapped source of employment opportunities gained by participation of Aborigines in cultural tourism.

By the time this report was released, Bob Hawke had gained leadership of the federal Labor Party and won government in 1983. Maddox (1991) maintained that while Hawke's policies were a recognisable continuation of Labor's tradition of reform, Hawke's government was concerned with promoting itself as one of instilling business confidence. Moreover, it went further and took 'consensus' to mean embracing some of the cherished policies of its opponents and adopted the notion of economic efficiency and rationalism (Maddox, 1991).

Davidson (1987) believed economic rationalism has been the established economic system throughout the Anglo-Saxon world for the last two decades, dominating bureaucracies, private think tanks, business lobbies, media and universities. Economic rationalism is an approach to economic decision making and Strachan (1998:1) declared 'the rational in economic rationalism comes from philosophy where it means guided by reason as opposed to emotions.' In essence, 'economic rationalism at its heart, is a refusal to spend money on the unnecessary' (Ellis, 1998: 1).

Economic considerations such as Aboriginal employment opportunities were highlighted in The Miller Report (Commonwealth Department of Employment \& Industrial Relations \& Department of Aboriginal Affairs, 1985), which alerted the federal government to benefits of cultural tourism such as employment opportunities for indigenous Australians. Furthermore, The Miller Report emphasised indigenous arts and crafts as a priority industry above other tourism ventures. This view was reiterated in the 1986 Kennedy Report (Commonwealth Department of Sport, Recreation and Tourism, 1986), along with the suggestion to develop a National Tourism Policy to facilitate Aboriginal involvement in tourism in culturally appropriate ways.

In 1988, the Department of the Arts, Sport, the Environment, Tourism and Territories [DASETT] claimed tourism to be the 'jewel in the crown' of Australian industry, and declared that Australia's Aboriginal culture provided a unique contribution to the national heritage and offered significant opportunities for the diversification of Australian tourism.

During 1989, the federal government Industries Assistance Commission [IAC] defined the role of government as facilitating the economic climate for tourism. The IAC (1989) acknowledged that growth in tourist activity was occurring on or near Aboriginal land, with increasing emphasis being placed on Aboriginal culture and heritage in the promotion of tourism, but admitted the net effect of exposure to tourism on the Aboriginal people was not clear. The outcome of such promotion was evident in a study conducted by the Australia Council in 1990 (Altman \& Finlayson, 1992), which found that 49\% of interna- 
tional visitors surveyed were interested in seeing and learning about Aboriginal art and culture.

In 1992, as a result of the legal land rights case of Eddie Mabo and Ors v. the State of Queensland, the federal High Court held that Australia was not terra nullius or empty land when settled by the British in 1788, but was occupied by ATSI peoples. Much attention was focused on the Mabo case and ATSI people, highlighted by the inclusion of ATSI tourism in the subsequent Keating Labor government's National Tourism Strategy (Commonwealth Department of Tourism [DOT], 1992). The strategy also noted the need to develop an Aboriginal Tourism Strategy to facilitate the growth of ATSI tourism enterprises and opportunities, and to foster links with the tourism industry.

The possibility for ATSI people to realise tourism opportunities became evident when the Office of National Tourism (1998b) acknowledged the passing of the Commonwealth Native Title Act 1993. Dillon (1987) and Altman and Finlayson (1992) believed that Aboriginal ownership of land should be the leverage that allows Aboriginal interests to extract a share of the tourism rent generated by businesses that provide goods and services to visitors. Moreover, the Pacific Asian Travel Association [PATA] (1990) stated that until the communities are confident that they can exercise effective and unchallenged control over the lands they occupy, they will continue to be distracted from all other concerns and will lack incentive to develop the tourism potential of the area.

In 1993, DOT identified as a priority for future action in the National Tourism Strategy Progress Report No. 1, the need to provide opportunities for indigenous employment in the tourism industry through the development of a National Aboriginal and Torres Strait Islander Tourism Strategy (Commonwealth Department of Tourism, 1993). The National Aboriginal and Torres Strait Islander Tourism Strategy Major Consultancy Report [NATSITIS: MCR] (1994), completed in June 1994, was undertaken to identify and establish the potential of ATSI participation in the Australian tourism industry. The Draft National Aboriginal and Torres Strait Islander Tourism Industry Strategy [DNATSITIS] was released in October 1994. This strategy specified objectives to enhance opportunities for self-determination, self-management and economic self-sufficiency in tourism for ATSI people. In 1997, three years after the release of the draft document and now with a Liberal National Coalition government in office under the leadership of John Howard, the National Aboriginal and Torres Strait Islander Tourism Industry Strategy [NATSITIS] was launched. NATSITIS was developed in response to recommendations of the Royal Commission into Aboriginal Deaths in Custody (1991), as were the National ATSI Rural Industry Strategy (ATSIC, 1997), the National ATSI Cultural Industry Strategy (ATSIC, 1997) and the Queensland Cultural Tourism: A Framework for Development (The Arts Office and QTTC, 1996) (Zeppel, 1999). According to the Office of National Tourism (1998a), NATSITIS provided a blueprint for future development of indigenous tourism in Australia such as the National Aboriginal Culture Centre at Darling Harbour in Sydney, which opened in July 1998.

Further research by the South Australian Tourism Commission [SATC] (1998), Aboriginal and Torres Strait Islander Commission [ATSIC] and the Office of National Tourism (1998a) focused on tourism as a means of providing ATSI 
people with an opportunity for economic advancement, business development, job and educational opportunities and the preservation of an ancient culture. At the same time, indigenous participation in Australian tourism was also viewed as a means of providing a unique product opportunity for the tourism industry, provided that, in any partnership between the tourism industry and ATSI people, both parties received education on varying issues (e.g. cross-cultural awareness and or management skills) for such partnerships to succeed.

In summary, the history of federal government involvement in ATSI tourism development suggests three recurring themes. These are: (1) the use of tourism as an economic and social tool for improving the well-being of ATSI people; (2) the development of tourism policy as a reactive response to broader political and social agendas; and (3) the use of ATSI tourism as an international marketing tool for the broader Australian tourism industry.

\section{A History of Queensland State Government Involvement in ATSI Tourism}

State government involvement in ATSI tourism in Queensland started with the Bjelke-Petersen National Party, which held office from 1957 to 1989. In describing this development, Craik (1991a) noted that the government created conditions that were conducive to the rapid development of the tourism industry. Tourism during this period emerged as a central plank in the political strategy of the party to the point that development was characterised by a high level of political intervention and vigorous promotion (Craik, 1991b). This approach attracted great political debate as to the veracity of development, with suggestions being made that the 'development at all costs' attitude often occurred at the expense of both mainstream and minority (i.e. ATSI) communities.

In 1979 the Queensland government Tourist Bureau became the Queensland Tourist and Travel Corporation under the Queensland Tourist and Travel Corporation [QTTC] Act 1979. In the early years of the QTTC, ATSI tourism did not appear to be of enough importance to warrant a specific unit within the organisation. Nonetheless, the Queensland government was recognising both the economic and cultural significance of ATSI people. Brennan (1992) claimed that during the mid 1970s to mid 1980s, the Queensland Parliament had passed more laws regarding Aboriginal land title and local government than any other parliament in Australia. While the laws regarding Aboriginal land title should have provided opportunities for new ATSI tourism development, the QTTC, by concentrating their interests on conventional developments such as coastal resorts, ignored both the potential for Aboriginal employment in tourism and Aboriginal tourism projects (Finlayson, 1991). In Queensland, the state tourism industry did not see Aboriginal tourism as having any substantial role to play within the industry, despite the fact that North Queensland and the Cape York Peninsula were attracting increased interest as a new commercial frontier (Finlayson, 1991).

Despite the apparent disinterest of the Queensland government in ATSI tourism during the early 1980s, in 1986, the Queensland Department of Aboriginal Affairs gave approval for the establishment of the Dreamtime Cultural Centre in Rockhampton. This was followed in 1987 by the formation of the privately 
owned and funded Tjapukai Aboriginal Dance Theatre in a village called Kuranda (near Cairns). Today, the company operates under the name of Tjapukai Aboriginal Cultural Park in Cairns, and has its own theatre complex. In 1992 it won the Australian Tourism Award for the 'Most Significant Local Attraction' in Australia. Based on the assumption that the Tjapukai Aboriginal Dance Theatre and the Dreamtime Cultural Centre assisted in preserving, maintaining and fostering indigenous cultural heritage, a dichotomy existed at this time. The Cultural Record Act 1987 was passed and, according to Fourmile (1992), it was 'a legislative blue print for the obliteration of much of the ATSI cultural heritage of Queensland.' Fourmile's argument would appear to be based on the grounds that the Act would legally sanction the exploitation of ATSI culture and heritage yet the Queensland Branch of the National Party of Australia showed little interest in expanding Aboriginal options for creative artistic work other than by providing a sales outlet for craft work (Finlayson, 1991).

During the late 1980s, tourism in Queensland was enjoying strong growth and ATSI tourism was receiving more attention through the opening of the Kuku-Yalanji Cultural Centre at Mossman Gorge in 1987, the establishment of the National Centre for Studies in Tourism at James Cook University in Townsville and, more significantly, World Expo 88 in Brisbane. In 1989, the Goss Labor government won office in Queensland and The Report of the Review Committee into the Aboriginal Arts and Crafts Industry (Commonwealth Department of Aboriginal Affairs, 1989) was released. The Report revealed that in comparison to Aboriginal arts and crafts in the Northern Territory, the arts and crafts of ATSI people of Queensland were largely unknown and unappreciated owing to the underdevelopment of the industry within the state. The Warrama Living History Centre in Cairns, funded by the federal Aboriginal Development Commission and the Queensland Department of Aboriginal Affairs (Finlayson, 1991) was opened in August 1990. Although the Centre operated only for a limited period of time, it was developed as a major cultural base for North Queensland ATSI communities. Through the aforementioned activity and policy development, not always directly related to tourism, Queensland state government interest in ATSI tourism appeared to be increasing. This was reflected in the formation of an ATSI tourism unit within the QTTC in 1992 and the appointment of the Aboriginal tourism officer in 1993. The purpose of the unit was to discover the nature of existing ATSI products and then to raise the awareness levels of relevant QTTC departments and the tourism industry concerning the existence of such products.

In December 1995, the Queensland government Department of Tourism, Sport and Youth (1995) launched the Draft Queensland Ecotourism Plan and the final Queensland Ecotourism Plan in 1997. In the same year, QTTC launched $A$ Framework for the Future, declaring QTTC would be actively involved in promoting the development of ATSI tourism product along with other special interest groups, which included markets such as wine, farming and rural tourism. Despite the QTTC goal to raise awareness levels of ATSI tourism, Miller (1995) maintained that QTTC support had not been converted into a stronger more reliable ATSI product. Furthermore, Fourmile (1992) reiterated sentiments from the 1989 Report of the Review Committee into the Aboriginal Arts and Crafts Industry (Commonwealth Department of Aboriginal Affairs, 1989), stating that despite 
the enormous potential for ATSI tourism in Queensland, the QTTC 'lags well behind its counterpart in the Northern Territory with regard to the official promotion of its State's indigenous cultures.'

In summary, Queensland state government involvement in ATSI tourism development can be described as relatively slow and sporadic, particularly when compared to federal government involvement. However, evident in development at the state level are the same kinds of government priorities as shown at federal level. These priorities included a belief in the value of tourism to improve the economic status of ATSI communities, and a corresponding view as to the importance of using ATSI tourism as an international marketing tool for the benefit of the state, as a whole. Moreover, in the case of both the federal and Queensland state governments' involvement in ATSI tourism, the activities of government have had a significant impact on the growth and direction of ATSI tourism. Despite these impacts, there is a need to empirically investigate the extent and nature of government involvement, particularly in terms of the influence of the broader context (e.g. issues in the economic environment), and in terms of the influence of the political ideologies of various governments.

\section{Methodology}

In order to examine the extent and nature of Australian government involvement in ATSI tourism policy an interpretive design was employed, drawing upon the complementary techniques of content analysis and hermeneutic analysis. Content analysis is a technique used for gathering and analysing the content of text, through procedures of categorisation, coding data and quantification (Neuman, 1997). Hermeneutics is a theory of meaning, emphasising a qualitative examination of text in an attempt to discover and interpret embedded meaning (Myers, 1995).

A purposive method of selection was used to establish a sample set of 17 policy documents that included content pertaining to ATSI tourism and that were identified by the researcher as being instrumental in shaping the tourism industry (see Table 6 in results section). These policies were derived from a sample frame of 72 potential government policies that were published between 1975 and 1999 by both federal and Queensland Liberal National Coalition and Labor governments (for a complete bibliography see Zeppel, 1999). ${ }^{2}$ The Liberal Party of Australia, the National Party and the Australian Labor Party are three of the major political parties in Australia. ${ }^{3}$ These parties and the dates they were in office as either federal or Queensland state government during the period 1975 to 1999 are shown in Table 1 and Table 2. The Liberal Party and National Party aspire to the ideology of laissez-faire capitalism and the Labor Party aspires to the ideology of social democratism (refer to Table 5 for a description of these ideologies).

It is generally assumed that the focus, goals and objectives of policy emanating from a laissez-faire government will differ from the focus, goals and objectives of policy developed by a socially democratic government. However, more fundamentally, there is an ongoing debate as to what constitutes policy (Jenkins, 1978; Davis et al., 1993). Therefore, in this study five different types of government documents were referred to as policy. First, legislation, that is a law which when 
Table 1 Australian federal governments and prime ministers in office from 1975 to 1999

\begin{tabular}{||l|l|l|l||}
\hline \hline Dates in office & Federal government & Prime minister & Political ideology \\
\hline Dec 1972-Nov 1975 & Labor & $\begin{array}{l}\text { Edward Gough } \\
\text { Whitlam }\end{array}$ & $\begin{array}{l}\text { Social } \\
\text { democtratism }\end{array}$ \\
\hline Nov 1975-March 1983 & $\begin{array}{l}\text { Liberal National } \\
\text { Coalition }\end{array}$ & $\begin{array}{l}\text { John Malcolm } \\
\text { Fraser }\end{array}$ & $\begin{array}{l}\text { Laissez-faire } \\
\text { capitalism }\end{array}$ \\
\hline March 1983-Dec 1991 & Labor & $\begin{array}{l}\text { Robert James } \\
\text { Hawke }\end{array}$ & $\begin{array}{l}\text { Social } \\
\text { democratism }\end{array}$ \\
\hline Dec 1991-March 1996 & Labor & Paul John Keating & $\begin{array}{l}\text { Social } \\
\text { democratism }\end{array}$ \\
\hline March 1996- & $\begin{array}{l}\text { Liberal National } \\
\text { Coalition }\end{array}$ & John Howard & $\begin{array}{l}\text { Laissez-faire } \\
\text { capitalism }\end{array}$ \\
\hline
\end{tabular}

Table 2 Queensland State governments and premiers in office from 1975 to 1999

\begin{tabular}{||l|l|l|l||}
\hline Dates in office & $\begin{array}{l}\text { Queensland state } \\
\text { government }\end{array}$ & Premier & Political ideology \\
\hline Aug 1968-Dec 1987 & $\begin{array}{l}\text { National Liberal } \\
\text { Coalition }\end{array}$ & $\begin{array}{l}\text { Sir Joannes } \\
\text { Bjelke-Petersen }\end{array}$ & $\begin{array}{l}\text { Laissez-faire } \\
\text { capitalism }\end{array}$ \\
\hline Dec 1987-Sept 1989 & $\begin{array}{l}\text { National Liberal } \\
\text { Coalition }\end{array}$ & Michael John Ahern & $\begin{array}{l}\text { Laissez-faire } \\
\text { capitalism }\end{array}$ \\
\hline Sept 1989-Sept 1989 & $\begin{array}{l}\text { National Liberal } \\
\text { Coalition }\end{array}$ & $\begin{array}{l}\text { Theo Russell } \\
\text { Cooper }\end{array}$ & $\begin{array}{l}\text { Laissez-faire } \\
\text { capitalism }\end{array}$ \\
\hline Dec 1989-Feb 1996 & Labor & Wayne Keith Goss & Social democratism \\
\hline Feb 1996-June 1998 & $\begin{array}{l}\text { National Liberal } \\
\text { Coalition }\end{array}$ & $\begin{array}{l}\text { Robert Edward } \\
\text { Borbidge }\end{array}$ & $\begin{array}{l}\text { Laissez-faire } \\
\text { capitalism }\end{array}$ \\
\hline June 1996 & Labor & $\begin{array}{l}\text { Peter Douglas } \\
\text { Beattie }\end{array}$ & Social democratism \\
\hline
\end{tabular}

passed by parliament becomes an Act of Parliament or a statute (Forrell, 1994). Second, plans which contain a particular objective, or set of principles, or course of action, that a government adopts at a given period (Parker, 1976). Third, strategies consisting of a comprehensive outline setting critical direction and guiding the allocation of resources to achieve long-term objectives. Fourth, reports often containing recommendations for future government actions and frequently used as a guide for plans and or legislation. Fifth, discussion papers, which are produced by an individual(s) or organisation, intended to stimulate debate on future government directions and action. Discussion papers generally include clearly identified objectives, and will also invite submissions from interested parties to review those objectives of the paper which are intended as a basis for the future development of government action.

In order to analyse objective one (i.e. to develop a catalogue of Australian federal and state government policies relevant to ATSI tourism between 1975 and 1999), a matrix was developed to organise and catalogue the 17 ATSI tourism policies. The information or variables analysed in the matrix appear in Table 3. 
Table 3 Matrix used to catalogue ATSI tourism policies

\begin{tabular}{|l|l|l|l|l||}
\hline $\begin{array}{l}\text { Number and } \\
\text { title }\end{array}$ & $\begin{array}{l}\text { Publication } \\
\text { date }\end{array}$ & Parameters of policy & $\begin{array}{l}\text { Government } \\
\text { source }\end{array}$ & Author \\
\hline $\begin{array}{l}\text { Systematically } \\
\text { labels policy } \\
\text { for ease of } \\
\text { identification. }\end{array}$ & $\begin{array}{l}\text { Identifies the } \\
\text { year of publi- } \\
\text { cation. }\end{array}$ & $\begin{array}{l}\text { Identifies policies as } \\
\text { legislation, plan, strat- } \\
\text { egy, report, discussion } \\
\text { paper; the total } \\
\text { number of document } \\
\text { pages and the number } \\
\text { of pages and percent- } \\
\text { age of content relevant } \\
\text { to ATSI tourism }\end{array}$ & $\begin{array}{l}\text { Identifies the } \\
\text { source of } \\
\text { policy, e.g. } \\
\text { Hawke } \\
\text { federal Labor } \\
\text { government }\end{array}$ & $\begin{array}{l}\text { Identifies the } \\
\text { organisa- } \\
\text { tion(s) and/or } \\
\text { government } \\
\text { department, } \\
\text { e.g. The Dept. } \\
\text { Sport, Recre- } \\
\text { ation \& } \\
\text { Tourism }\end{array}$ \\
\hline
\end{tabular}

Table 4 Focus of ATSI tourism policies

\begin{tabular}{||l|l|l||}
\hline Environments & Frequency & Percentage of sample set \\
\hline $\begin{array}{l}\text { Focus of Policies Relating to the } \\
\text { Social EnvironmentFocus of Policies } \\
\text { Relating to the Economic } \\
\text { EnvironmentFocus of Policies } \\
\text { Relating to the Political } \\
\text { EnvironmentFocus of Policies } \\
\text { Relating to the Ecological Environ- } \\
\text { ment }\end{array}$ & $\begin{array}{l}\text { Record each focus } \\
\text { once per policy, as } \\
\text { identified. } \\
\text { Total the focus of poli- } \\
\text { cies appearing in each } \\
\text { environment }\end{array}$ & $\begin{array}{l}\text { Express frequency of } \\
\text { each focus as percent- } \\
\text { age of 17 policies }\end{array}$ \\
\hline
\end{tabular}

The second objective of the study (i.e. to examine the focus of ATSI tourism policy in relation to the broader social, economic, political and ecological environments), was analysed by determining the frequency and percentage of content that reflected four major environments. These environments were the social environment (e.g. indigenous self-determination), the economic environment (e.g. increase ATSI economic independence), the political environment (e.g. Land Rights) and the ecological environment (e.g., environmentally sustainable development).

To assess the focus of these tourism policies, it was necessary to create a matrix, as shown in Table 4, in which the focus of policies could be recorded under the appropriate environment (e.g. ATSI employment was listed under Economic environment). However, the focus of a policy was recorded in one or more environments (but only once per environment) as there were indistinct boundaries between the economic, social, political and ecological environments. For example, cultural heritage was regarded as a focus relating to both the economic and political environments. When all policies were analysed in relation to policy focus, the data was recorded numerically, and then as a percentage of the 17 policies (e.g. the policy focus of ATSI employment was identified in 16 of the 17 policies, a score of $94 \%$ ). These percentages were then ranked to identify the predominant environment of the 17 policies.

In order to address the study's third objective (i.e. to determine what political ideologies have been reflected in ATSI tourism policies), three political ideologies - social democratism, laissez-faire capitalism and economic rationalism were identified as being discernible in Australian politics during the study 
Table 5 Framework of political ideologies

\begin{tabular}{|c|c|c|}
\hline Ideology label & Literature source & Indicator \\
\hline cial & $\begin{array}{l}\text { 1. Encourages community services, voluntary } \\
\text { groups and associations (Coombe et al., } \\
\text { 1982: 77) } \\
\text { 2. Deep concern for the disadvantaged } \\
\text { (Kersbergen, 1995) } \\
\text { 3. Encourages distribution of the wealth } \\
\text { (Schott, 1987) } \\
\text { 4. Strong labour movement (Swank \& Hicks } \\
\text { cited in Kersbergen, 1995) } \\
\text { 5. Provision of interventions and regulations } \\
\text { by the state (Callaghan, 1987) } \\
\text { 6. Emphasises public sector bureaucracy } \\
\text { (Forell, 1994) }\end{array}$ & $\begin{array}{l}\text { 2. Equal opportunity } \\
\text { 3. Reduce status and } \\
\text { class } \\
\text { 4. Eliminate exploita- } \\
\text { tion } \\
\text { 5. Big government } \\
\text { 6. High level of gov- } \\
\text { ernment spending }\end{array}$ \\
\hline $\begin{array}{l}\text { Laissez-faire } \\
\text { capitalism }\end{array}$ & $\begin{array}{l}\text { 1. Encourages self-sufficiency (Sawer, 1982) } \\
\text { 2. The right to think and act on ones own inde- } \\
\text { pendent judgement (Rand, 1999) } \\
\text { 3. Encourages private wealth (Coombe et al., } \\
\text { 1982: 14) } \\
\text { 4. Survival of the fittest through natural selec- } \\
\text { tion (Davidson, 1987) } \\
\text { 5. Non-interventionist and deregulatory } \\
\text { (Forell, 1994) } \\
\text { 6. Emphasises welfare, voluntary and charita- } \\
\text { ble services (Hansard cited in Sawer, 1982) }\end{array}$ & $\begin{array}{l}\text { 1. Individualism } \\
\text { 2. Freedom of choice } \\
\text { 3. Laws of private } \\
\text { property } \\
\text { 4. Deal with others as } \\
\text { traders } \\
\text { 5. Small government } \\
\text { 6. Minimal govern- } \\
\text { ment spending }\end{array}$ \\
\hline $\begin{array}{l}\text { Economic } \\
\text { rationalism }\end{array}$ & $\begin{array}{l}\text { 1. Guided by reason rather than emotion } \\
\text { (Strachan, 1998) } \\
\text { 2. Free trade, global and competitive markets } \\
\text { (Pusey, 1992) } \\
\text { 3. Human resources are tradable commodities } \\
\text { (Ellis, 1997) } \\
\text { 4. Limited government policies protecting the } \\
\text { wider community (Marinova, 1997) } \\
\text { 5. Practice of reducing the public sector } \\
\text { (Pusey, 1991) } \\
\text { 6. Vertical and horizontal concentration of } \\
\text { business ownership (Galbraith cited in } \\
\text { Strachan, 1998 }\end{array}$ & $\begin{array}{l}\text { 1. Objectivity } \\
\text { 2. Economic } \\
\text { efficiency } \\
\text { 3. Production } \\
\text { processes } \\
\text { 4. } \text { Community } \\
\text { fragmentation } \\
\text { 5. Rationalism } \\
\text { 6. Oligopoly }\end{array}$ \\
\hline
\end{tabular}

period (Byrt \& Crean, 1972; Forell, 1994; Davidson, 1987). A framework of political ideologies containing latent codes (i.e. indicators of each political ideology) for policy analysis was developed from a review of political science literature. Table 5 identifies the six characteristics allocated as the indicators for each of the ideologies. Although the criteria were identified by numerous authors, Coombe et al. (1982) identified all six criteria as characterising laissez-faire capitalism and social democratism, and Sturman (1997) identified all six criteria as characterising economic rationalism. 
To analyse the 17 policies, singular or multiple words and or phrases central to the policy were selected, recorded and allocated indicators according to the Framework of Political Ideologies.

Indicators were grouped according to their respective ideology (e.g. economic efficiency and production process = economic rationalism). The frequency of each indicator per policy was recorded numerically, and then as a percentage to rank the political ideologies underpinning the policies. For example, identified in NATSITIS were: 39 (48\%) indicators of laissez-faire capitalism; $32(39 \%)$ indicators of economic rationalism; and $10(12 \%)$ indicators of social democratism. Finally, a narrative description of all indicators within their respective groupings was written for each policy.

The three research procedures were each subjected to a pre-test using the National Aboriginal and Torres Strait Islander Tourism Industry Strategy and the Draft Queensland Ecotourism Plan. The pre-test revealed the catalogue provided ease of referencing policy data and analytic memos assisted in providing reliability for the study. Furthermore, the analysis of policy data utilising the framework of political ideologies prompted researcher familiarity with each policy.

The pre-tests also revealed limitations to the research design. For instance, the policies included in the sample set of the study were analysed only in terms of the written content contained within them and did not include aspects such as the policymakers, formulation, implementation and evaluation of the policies. Where policies were not specifically focused on ATSI tourism, but included sections that referred to the issue, only these sections were analysed in full. This could result in misinterpretation of the policy even though the researcher was familiar with the broad context of each policy. During the analysis of the documents, the primary (first listed) researcher's own awareness of factors outside the social and historical context may have distorted meanings and understandings (Gadamer, 1976). Subjectivity is an essential part of the interpretive analysis, and the primary researcher's values and interests and Anglo-Celtic background may have influenced interpretation of the text pertaining to ATSI people.

\section{Results}

The findings of the study from the policy catalogue are reported in Table 6 . Inspection of Table 6 reveals several important results in relation to the overall development of ATSI tourism policy. First, the significant period in which either a federal or Queensland state government published general tourism policies with some ATSI content was 1985 to 1997. Federal Labor governments, and notably the Department of the Prime Minister and Cabinet, one of three Commonwealth Departments that control financial policy, were the main source and author of the policies. Second, the primary types of ATSI tourism policy documents were plans and reports accounting for half $(58 \%)$ of the policies. Strategies accounted for $29 \%$, while discussion papers accounted for $13 \%$ of the policies. Third, the policy catalogue identified the total number of pages published in the 17 policies was 2151, with the total number of pages allocated to ATSI tourism being 132. Thus the percentage of ATSI tourism content within the policies was $6 \%$. However, if NATSITIS, the only policy specifically published for ATSI tourism is 
Table 6 Catalogue of federal and Queensland State ATSI tourism policy: 1975-1999

\begin{tabular}{|c|c|c|c|c|}
\hline $\begin{array}{l}\text { Number and } \\
\text { title }\end{array}$ & $\begin{array}{l}\text { Publication } \\
\text { date }\end{array}$ & $\begin{array}{l}\text { Parameters of } \\
\text { policy }\end{array}$ & $\begin{array}{l}\text { Government } \\
\text { source }\end{array}$ & Author \\
\hline $\begin{array}{l}\text { 1. Final Report of } \\
\text { the House of Rep- } \\
\text { resentatives Select } \\
\text { Committee on } \\
\text { Tourism } \\
\end{array}$ & 1978 & $\begin{array}{l}\text { Report }-109 \text { pages } \\
\text { ATSI Ref: pp. } 23- \\
26 \\
\text { ATSI Content: } \\
3.6 \%\end{array}$ & $\begin{array}{l}\text { Fraser Federal } \\
\text { Liberal Coalition }\end{array}$ & $\begin{array}{l}\text { Dept of Prime } \\
\text { Minister \& Cabinet }\end{array}$ \\
\hline $\begin{array}{l}\text { 2. Report of Com- } \\
\text { mittee of the } \\
\text { Review of } \\
\text { Aboriginal } \\
\text { Employment } \\
\text { \&Training Pro- } \\
\text { grams }\end{array}$ & 1985 & $\begin{array}{l}\text { Report }-453 \text { pages } \\
\text { ATSI Ref: pp. 317- } \\
334 \\
\text { ATSI Content: } \\
3.75 \%\end{array}$ & $\begin{array}{l}\text { Hawke Federal } \\
\text { Labor }\end{array}$ & $\begin{array}{l}\text { Dept of } \\
\text { Employment \& } \\
\text { Industrial } \\
\text { Relations \& Dept } \\
\text { of Aboriginal } \\
\text { Affairs }\end{array}$ \\
\hline $\begin{array}{l}\text { 3. National Aborigi- } \\
\text { nal Bicentennial } \\
\text { Objectives }\end{array}$ & 1985 & $\begin{array}{l}\text { Discussion Paper - } \\
69 \text { pages } \\
\text { ATSI Ref: pp. } 46- \\
\text { 47 } \\
\text { ATSI Content: } \\
2.8 \% \\
\end{array}$ & $\begin{array}{l}\text { Hawke Federal } \\
\text { Labor }\end{array}$ & $\begin{array}{l}\text { Aboriginal } \\
\text { Development } \\
\text { Commission }\end{array}$ \\
\hline $\begin{array}{l}\text { 4. Report of the } \\
\text { Australian Gov- } \\
\text { ernment Inquiry } \\
\text { into Tourism }\end{array}$ & 1986 & $\begin{array}{l}\text { Report - Vol. } 1 \\
\text { 253 pages } \\
\text { ATSI Ref: pp. } 62- \\
64 \\
\text { ATSI Content: } 1 \% \\
\end{array}$ & $\begin{array}{l}\text { Hawke Federal } \\
\text { Labor }\end{array}$ & $\begin{array}{l}\text { Dept of Sport, } \\
\text { Recreation \& } \\
\text { Tourism }\end{array}$ \\
\hline $\begin{array}{l}\text { 5. Aboriginal } \\
\text { Employment } \\
\text { Development } \\
\text { Policy }\end{array}$ & 1987 & $\begin{array}{l}\text { Plan - } 17 \text { pages } \\
\text { ATSI Ref: pp. } 7,10 \\
\text { ATSI Content: } 11 \%\end{array}$ & $\begin{array}{l}\text { Hawke Federal } \\
\text { Labor }\end{array}$ & $\begin{array}{l}\text { Ministers for } \\
\text { Aboriginal Affairs, } \\
\text { Employment, } \\
\text { Education } \\
\text { \&Training \& } \\
\text { mployment } \\
\text { Services \& Youth } \\
\text { Affairs } \\
\end{array}$ \\
\hline $\begin{array}{l}\text { 6. Directions for } \\
\text { Tourism }\end{array}$ & 1988 & $\begin{array}{l}\text { Discussion Paper - } \\
\text { 97 pages } \\
\text { ATSI Ref: pp.82-84 } \\
\text { ATSI Content: } 3 \%\end{array}$ & $\begin{array}{l}\text { Hawke Federal } \\
\text { Labor }\end{array}$ & $\begin{array}{l}\text { Dept of the Arts, } \\
\text { Sport, the } \\
\text { Environment, } \\
\text { Tourism \& the } \\
\text { Territories }\end{array}$ \\
\hline $\begin{array}{l}\text { 7. Travel and } \\
\text { Tourism }\end{array}$ & 1989 & $\begin{array}{l}\text { Report number } \\
423-127 \text { pages } \\
\text { ATSI Ref. pp. } 183- \\
185 \\
\text { ATSI Content: } 2 \% \\
\end{array}$ & $\begin{array}{l}\text { Hawke Federal } \\
\text { Labor }\end{array}$ & $\begin{array}{l}\text { Industries } \\
\text { Assistance } \\
\text { Commission }\end{array}$ \\
\hline $\begin{array}{l}\text { 8. Royal Commis- } \\
\text { sion into Aborigi- } \\
\text { nal Deaths in } \\
\text { Custody }\end{array}$ & 1991 & $\begin{array}{l}\text { Report - Vol } 4.492 \\
\text { pages } \\
\text { ATSI Ref: pp. } 403- \\
406 \\
\text { ATSI Content: } \\
.81 \% \\
\end{array}$ & $\begin{array}{l}\text { Keating Federal } \\
\text { Labor } \\
\\
\end{array}$ & $\begin{array}{l}\text { Dept of Prime } \\
\text { Minister \& Cabinet }\end{array}$ \\
\hline $\begin{array}{l}\text { 9. Tourism: Austra- } \\
\text { lia's Passport to } \\
\text { Growth } \\
\text { (summary) }\end{array}$ & 1992 & $\begin{array}{l}\text { Strategy - } 15 \text { pages } \\
\text { ATSI Ref: pp. } 11, \\
13 \\
\text { ATSI Content: } \\
.13 \%\end{array}$ & $\begin{array}{l}\text { Keating Federal } \\
\text { Labor }\end{array}$ & Dept of Tourism \\
\hline
\end{tabular}


Table 6 (cont.) Catalogue of federal and Queensland State ATSI tourism policy: 19751999

\begin{tabular}{|c|c|c|c|c|}
\hline $\begin{array}{l}\text { Number and } \\
\text { title }\end{array}$ & $\begin{array}{l}\text { Publication } \\
\text { date }\end{array}$ & $\begin{array}{l}\text { Parameters of } \\
\text { policy }\end{array}$ & $\begin{array}{l}\text { Government } \\
\text { source }\end{array}$ & Author \\
\hline $\begin{array}{l}\text { 10. Access and Equity } \\
\text { Plan: Tourism } \\
\text { Portfolio }\end{array}$ & 1993 & $\begin{array}{l}\text { Plan - } 15 \text { pages } \\
\text { ATSI Ref: pp.5-7 } \\
\text { ATSI Content: } 20 \%\end{array}$ & $\begin{array}{l}\text { Keating Federal } \\
\text { Labor }\end{array}$ & $\begin{array}{l}\text { Office of } \\
\text { Multicultural } \\
\text { Affairs in the Dept } \\
\text { of the Prime } \\
\text { Minister \& Cabinet }\end{array}$ \\
\hline $\begin{array}{l}\text { 11. National } \\
\text { Ecotourism Plan }\end{array}$ & 1994 & $\begin{array}{l}\text { Strategy }-68 \text { pages } \\
\text { ATSI Ref: pp. } 42- \\
45 \\
\text { ATSI Content: } 4 \%\end{array}$ & $\begin{array}{l}\text { Keating Federal } \\
\text { Labor }\end{array}$ & Dept of Tourism \\
\hline 12. Creative Nation & 1994 & $\begin{array}{l}\text { Plan - } 101 \text { pages } \\
\text { ATSI Ref: pp. } 20- \\
21,100 \\
\text { ATSI Content: } 3 \% \\
\end{array}$ & $\begin{array}{l}\text { Keating Federal } \\
\text { Labor }\end{array}$ & $\begin{array}{l}\text { Dept of } \\
\text { Communications } \\
\text { \& the Arts }\end{array}$ \\
\hline $\begin{array}{l}\text { 13. Draft Queensland } \\
\text { Ecotourism Plan }\end{array}$ & 1995 & $\begin{array}{l}\text { Strategy }-88 \text { pages } \\
\text { ATSI Ref: pp. } 17,55 \\
\text { ATSI Content: } 2 \% \\
\end{array}$ & $\begin{array}{l}\text { Goss QLD State } \\
\text { Labor }\end{array}$ & $\begin{array}{l}\text { Dept of Tourism, } \\
\text { Sport and Racing }\end{array}$ \\
\hline $\begin{array}{l}\text { 14. National ATSI } \\
\text { Tourism Industry } \\
\text { Strategy }\end{array}$ & 1997 & $\begin{array}{l}\text { Strategy - } 76 \text { pages } \\
\text { ATSI Ref: pp. } 1-76 \\
\text { ATSI Content: } \\
100 \%\end{array}$ & $\begin{array}{l}\text { Howard Federal } \\
\text { Liberal Coalition }\end{array}$ & $\begin{array}{l}\text { ATSIC \& Office of } \\
\text { National Tourism }\end{array}$ \\
\hline $\begin{array}{l}\text { 15. Framework for } \\
\text { the Future }\end{array}$ & 1997 & $\begin{array}{l}\text { Plan }-25 \text { pages } \\
\text { ATSI Ref: } p .22 \\
\text { ATSI Content: } 4 \% \\
\end{array}$ & \begin{tabular}{|l|} 
Borbidge QLD \\
State National \\
Coalition \\
\end{tabular} & $\begin{array}{l}\text { Dept of Tourism, } \\
\text { Small Business \& } \\
\text { Industry }\end{array}$ \\
\hline $\begin{array}{l}\text { 16. Queensland } \\
\text { Ecotourism Plan }\end{array}$ & 1997 & $\begin{array}{l}\text { Plan - } 81 \text { pages } \\
\text { ATSI Ref: pp.29, } 52 \\
\text { ATSI Content: } \\
2.4 \%\end{array}$ & $\begin{array}{l}\text { Borbidge QLD } \\
\text { State National } \\
\text { Coalition }\end{array}$ & $\begin{array}{l}\text { Dept of Tourism, } \\
\text { Small Business \& } \\
\text { Industry, Dept of } \\
\text { Environment \& } \\
\text { Dept of Natural } \\
\text { Resources } \\
\end{array}$ \\
\hline $\begin{array}{l}\text { 17. Queensland ATSI } \\
\text { Economic Devel- } \\
\text { opment Strategy }\end{array}$ & 1998 & $\begin{array}{l}\text { Strategy - } 65 \text { pages } \\
\text { ATSI Ref: pp. } 45- \\
46 \\
\text { ATSI Content: } 3 \%\end{array}$ & $\begin{array}{l}\text { Beattie QLD State } \\
\text { Labor }\end{array}$ & $\begin{array}{l}\text { Dept of Economic } \\
\text { Development } \\
\text { \&Trade \& Dept of } \\
\text { Families, Youth \& } \\
\text { Community Care } \\
\end{array}$ \\
\hline
\end{tabular}

Note. ATSI Ref: page numbers in each policy addressing ATSI tourism

Content: ATSI Ref: expressed as a percentage

Shaded area denotes policy that is specifically developed for ATSI tourism

excluded, the percentage of content allocated to ATSI tourism within the 16 remaining policies is $2.7 \%$.

The findings relating to the second objective of the study are shown in Table 7. The major finding relating to the focus of policy content was the degree of influence of the economic environment, appearing 93 times and accounting for just under half $(48 \%)$ of the focus of policies.

The second most predominant environment was the social environment, appearing 55 times and accounting for just over a quarter (28\%) of the focus of policies. The political and ecological environments combined, account for the remaining quarter (approximately 23\%) and appeared 25 and 20 times respectively in the focus of the policies.

The focus of policies from the predominant economic environment included 
Table 7 Focus of ATSI tourism policies

\begin{tabular}{|c|c|c|}
\hline Focus of policies relating to the economic environment & Frequency & $\begin{array}{l}\text { Percentage of } \\
\text { sample set }\end{array}$ \\
\hline 1. ATSI tourism as a means of increasing ATSI employment & 16 & 94 \\
\hline 2. Utilise and market natural and cultural heritage of ATSI people & 16 & 94 \\
\hline 3. Self-generated business (e.g. Promotion of private enterprise) & 10 & 58 \\
\hline $\begin{array}{l}\text { 4. Promotion of Australian tourism to compete in the global } \\
\text { tourism industry }\end{array}$ & 9 & 52 \\
\hline $\begin{array}{l}\text { 5. Increase ATIS economic independence through employment or } \\
\text { partnership }\end{array}$ & 8 & 47 \\
\hline 6. Tourism as a means of increasing Gross Domestic Product & 7 & 41 \\
\hline $\begin{array}{l}\text { 7. Economic significance of tourism industry to the Australian } \\
\text { economy }\end{array}$ & 7 & 41 \\
\hline $\begin{array}{l}\text { 8. Increase resource funding to enable ATSI people to participate } \\
\text { in tourism }\end{array}$ & 7 & 41 \\
\hline $\begin{array}{l}\text { 9. Development of ATSI economic base through the vehicle of } \\
\text { tourism }\end{array}$ & 6 & 35 \\
\hline 10. Sustainable economic development & 4 & 23 \\
\hline $\begin{array}{l}\text { 11. Economic well being of ATSI people (e.g. Economic independ- } \\
\text { ence) }\end{array}$ & 3 & 17 \\
\hline TOTAL & 93 & 48.2 \\
\hline Focus of policies relating to the social environment & & $\%$ \\
\hline $\begin{array}{l}\text { 1. Increase ATSI education (e.g. Primary, secondary, tertiary, mar- } \\
\text { keting \& management skills) }\end{array}$ & 8 & 47 \\
\hline 2. Self-determination and reconciliation for ATSI people & 7 & 41 \\
\hline 3. Growth opportunities for ATSI communities & 6 & 35 \\
\hline $\begin{array}{l}\text { 4. Participation in tourism enterprises by ATSI communities (con- } \\
\text { sultation, negotiation, participation in joint ventures) }\end{array}$ & 6 & 35 \\
\hline 5. Socially sustainable outcomes for ATSI people & 5 & 29 \\
\hline $\begin{array}{l}\text { 6. Quality of tourism experience (e.g. Positive interaction between } \\
\text { visitor and host) }\end{array}$ & 5 & 29 \\
\hline 7. Ensure favourable social outcomes for ATSI people & 5 & 29 \\
\hline 8. Sustainability of ATSI cultures & 5 & 29 \\
\hline 9. Remedying social disadvantage & 4 & 23 \\
\hline 10. Reduce discrimination & 2 & 11 \\
\hline 11. Reduce ATSI unemployment & 2 & 11 \\
\hline TOTAL & 55 & 28.5 \\
\hline Focus of policies relating to the political environment & & $\%$ \\
\hline $\begin{array}{l}\text { 1. Government acknowledgement of needs of ATSI people (e.g. } \\
\text { Education, funding) }\end{array}$ & 17 & 100 \\
\hline 2. Land Rights & 5 & 29 \\
\hline $\begin{array}{l}\text { 3. Inadequate government policies (e.g. Which do not account for } \\
\text { all, or subjugate, issues) }\end{array}$ & 3 & 17 \\
\hline TOTAL & 25 & 12.9 \\
\hline
\end{tabular}


Table 7 cont' $\mathbf{d}$ Focus of ATSI tourism policies

\begin{tabular}{||l|c|c||}
\hline \hline Focus of policies relating to the economic environment & Frequency & $\begin{array}{c}\text { Percentage of } \\
\text { sample set }\end{array}$ \\
\hline 1. Sustainable tourism & 10 & 58 \\
\hline $\begin{array}{l}\text { 2. Conservation of natural and cultural ATSI heritage } \\
\text { Improve environmental education (e.g. Visitor enlightenment } \\
\text { throug knowledge \& skills) }\end{array}$ & 5 & 29 \\
\hline 4. Environmental protection and management & 2 & 17 \\
\hline TOTAL & 20 & 10.4 \\
\hline GRAND TOTAL & 193 & 100 \\
\hline
\end{tabular}

Note. Frequency denotes the individual focus was cited in a policy at least once.

Percentage denotes sum of issues expressed as a percentage of 17 policies.

increasing employment opportunities, evident in 16 (94\%) of the 17 policies. The generation of self-employment for ATSI people was viewed as the means to enter the tourism industry in $10(58 \%)$ of the policies. For instance, NATSITIS highlighted the need for ATSI people to form partnerships with industry, and the need for development of an ATSI tourism product to facilitate increased employment and business opportunities for ATSI people.

The next most predominant environment was the social environment in which the focus of increased ATSI education was referred to in eight (47\%) of the 17 policies. For example, NATSITIS claimed 'available and suitable training courses' should be provided through private sector scholarships and apprenticeships. Identified within seven $(41 \%)$ of the policies was the focus pertaining to self-determination and the right of ATSI people to freely choose to participate in tourism, while two $(11 \%)$ of the 17 policies made indirect reference to overcoming racial discrimination. NATSITIS acknowledged there could be 'a perceived or actual discrimination in the workplace, which discourages Aboriginal people from applying for jobs, or which leads them to leave their jobs'.

Within the broader political focus of the policies was the recognition of government responsibilities, represented in all 17 of the policies. The Report of the Committee of Review of Aboriginal Employment and Training Programs claimed there was an 'urgent need for governments to develop policies that ensure Aboriginal interests are not only protected but enhanced where such development occurs'. Land rights was another focus, raised in five (29\%) of the policies. The National Aboriginal Bicentennial Objectives claimed the enactment of land rights would recognize 'the rights of Aboriginal people to inalienable freehold title to land to meet their needs and in recognition of the loss of their inherent rights'.

The least predominant environment was the ecological environment, and sustainability pertaining to both the environment and ATSI tourism was raised in $10(58 \%)$ of the 17 policies. Creative Nation stated that the government's responsibility was to 'preserve the natural heritage.' The National Ecotourism Strategy included the claim that government must 'provide leadership in the promotion of models of ecologically sustainable tourism'.

The results of the third objective of the study are presented in Table 8 and illustrate the frequency and corresponding percentage of the ideological indicators 


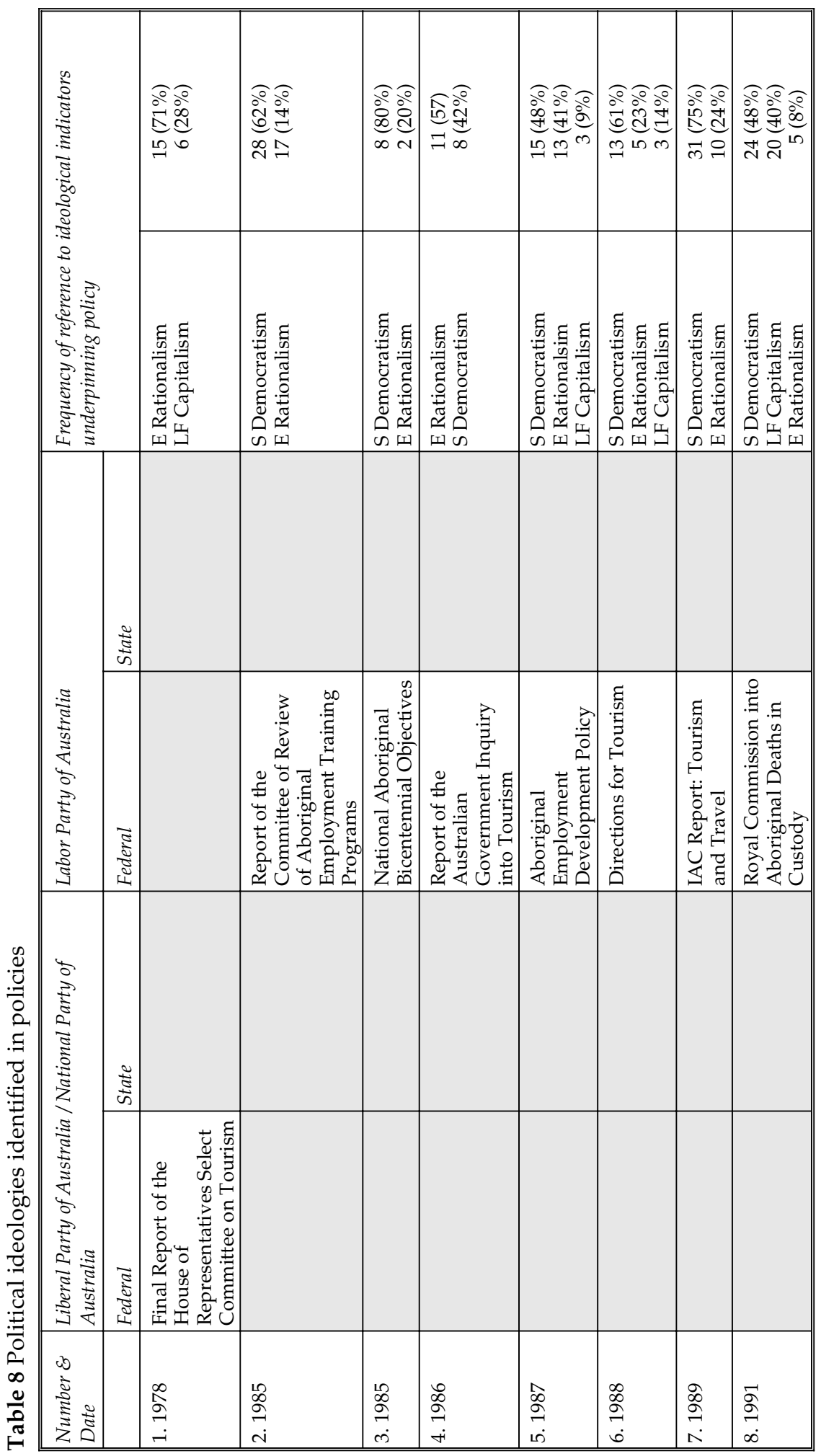




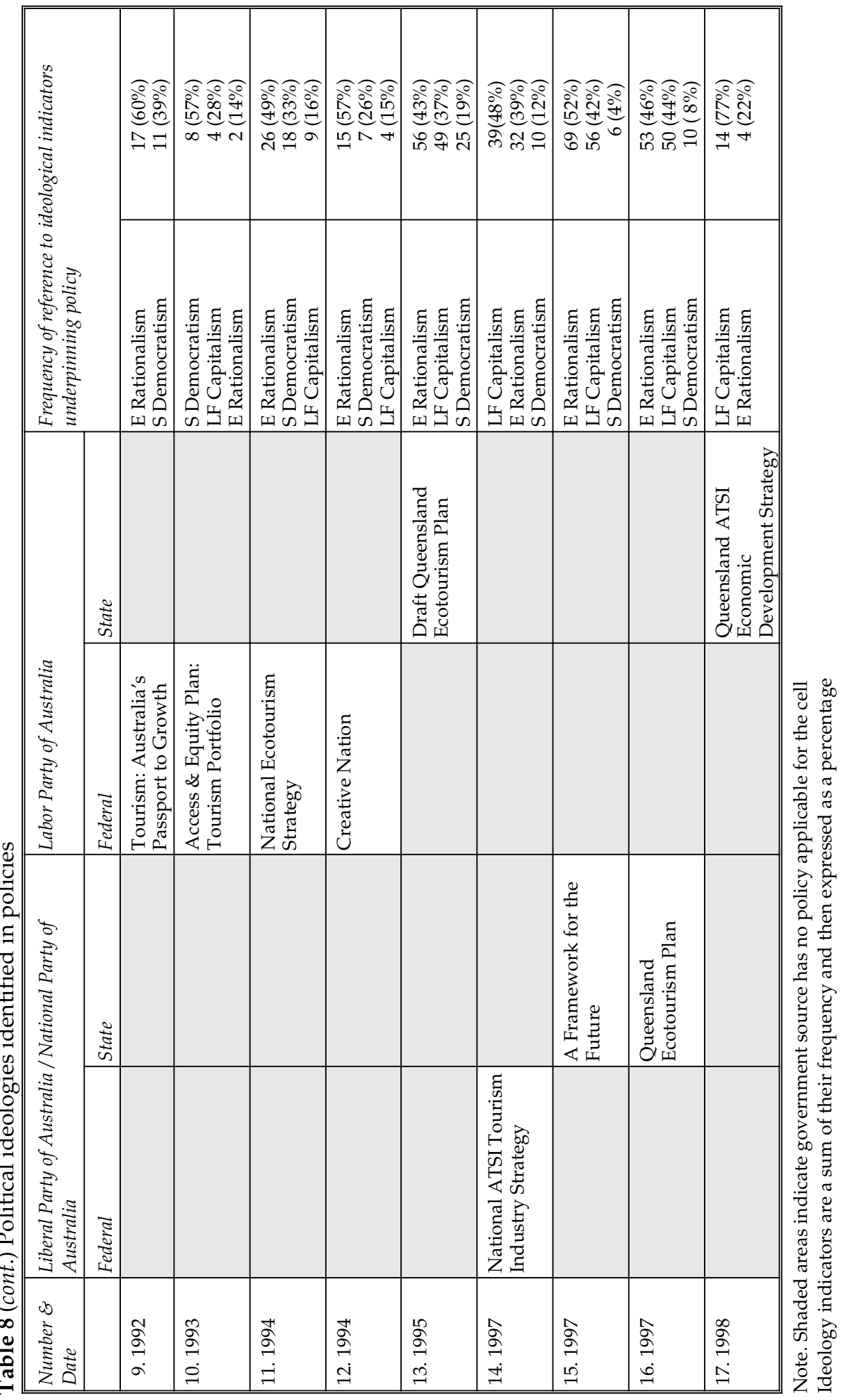


identified in each policy. In Table 8, the policies are numbered in the same order as the policy catalogue (Table 6) and placed under their respective government source.

Most significantly, results from the interpretive analysis revealed that none of the 17 policies were underpinned by a single predominant ideology; that is, none of the policies were purely representative of laissez-faire capitalism, social democratism or economic rationalism. However, as shown in Table 8, constant throughout the interpretive analysis was the identification of economic rationalism, underpinning every policy, albeit to varying degrees, over the time span of 25 years of successive governments.

Eight policies (numbers 1, 4, 9, 11, 12, 13, 15, 16) revealed the predominant ideology underpinning the policy was not the same ideology to that of the government of the day. As shown in Table 8, the socially democratic Labor governments demonstrated a propensity towards an economic rationalist approach to ATSI tourism policy. The 11 policies sourced from Labor governments had a strong component of economic rationalism within the policy and in five of the policies (numbers 4, 9, 11,12,13) economic rationalism indicators were a considerably higher percentage than those of social democratism. All of these policies displayed economic efficient characteristics such as the need to 'encourage increased investor confidence in the industry', or production process characteristics such as to 'encourage increased involvement by indigenous people in the industry to enhance visitor experiences'.

Similarly, the policies of the Liberal Coalition governments revealed economic rationalism characteristics influencing the content of the policies. Of the five Liberal coalition policies, the percentage of economic rationalism indicators in three of these policies (numbers 1,15,16) were higher than those of laissez-faire capitalism. For instance, in policy number 1, The Final Report of the House of Representatives Select Committee on Tourism, there were 15 (71\%) economic rationalism indicators and $6(28 \%)$ laissez-faire capitalism indicators.

In summary, excluding NATSITIS, which allocated $100 \%$ of the content to ATSI tourism, very little of the policy content (2.7\%) from the sample set was allocated to ATSI tourism. Furthermore, the content demonstrated that the focus of the policies was influenced, to varying degrees, by economic considerations inherent in the policies. This result is supported by the analysis of political ideology that identified all 17 policies contained characteristics of economic rationalism. Thus, while in essence, the ideology of the government of the day underpins ATSI tourism policies, the results indicate federal and State governments of all persuasions have converged, to varying degrees, towards a common economically rationalist compromise in policies pertaining to ATSI tourism.

\section{Discussion}

The development of a catalogue of federal and Queensland state governments' policies relating to ATSI tourism and published between 1975 and 1999 revealed three key findings: (1) a disparate approach to the development of specific ATSI tourism policies; (2) a relatively small amount of policy emphasis given to ATSI tourism within the content of regularly published policies compared with policy content pertaining to mainstream tourism; and (3) an apparent reac- 
tive acknowledgment of government responsibility to improve the social and economic environments of ATSI people. Each of these findings is now discussed in terms of its relevance to ATSI tourism.

The policy catalogue (Table 6) confirms that there is a disparate approach to development of ATSI tourism despite the publication of a major policy containing references to ATSI tourism almost every year from 1975 to 1999. Although successive governments developed policies that included content pertaining to ATSI tourism, there is an apparent lack of continuity in the sources, the authors and the types of policies. The results revealed the most significant period in which policy pertaining to ATSI tourism was developed was between 1985 and 1997. The predominance of ATSI tourism policy during this period could be attributed to the Hawke federal Labor government's belief that the virtual neglect of the tourism industry by their Liberal coalition predecessors 'culminated in little more than lip service being paid to the benefits which tourism could provide to economic and social development' (Brown, 1983:1). Successive federal Labor governments of Hawke and Keating, published 11 (64\%) of the 17 policies pertaining to ATSI tourism. However, each policy appeared under the auspices of bigger agendas with ATSI tourism being merely a small component. This was highlighted in Table 6, which showed that no specific ATSI tourism policy was produced during a combined 13-year period in office, even though it appears that both Labor governments were cognisant of the potential of ATSI tourism.

In comparison, the federal Liberal National Coalition governments produced only two policies from 1975 to 1999. The Liberal National Coalition government led by Malcolm Fraser produced one policy (i.e. Final Report of the House of Representatives Select Committee on Tourism), addressing ATSI tourism, while John Howard's federal government also produced one policy, the 1997 NATSITIS. Interestingly, Keating's Labor government initiated NATSITIS. What is particularly notable about the latter policy is that it represents the most significant policy out of the total 17 policies that was formulated for ATSI tourism. Despite the significance of this policy, the same charges of indifference to ATSI tourism might be laid on the Liberal National Coalition governments, reflected in a meagre contribution to the 17 ATSI tourism policies published over their combined 13-year period in office.

However, neglect for developing ATSI tourism by federal Labor and Liberal National Coalition governments pales into insignificance when compared to the relative lack of ATSI tourism policies developed by successive Queensland governments from 1975 to 1990 (see Craik, 1991a). Queensland has had a long tradition of seeing itself as different from other states in that it showed a pioneer spirit through fostering entrepreneurship in tourism development. This entrepreneurship included what were at the time, somewhat unorthodox approaches, such as special government legislation and contracts to underwrite new developments (Patience, 1985). For instance, projects such as Sanctuary Cove, Jupiter's Casino and the Port Douglas Mirage are examples of government sanctioned developments. The minimal representation of Queensland state government policies shown in the catalogue supports suggestions that ATSI tourism was not a priority of the government during this 15-year period. Further evidence to support this explanation is provided by Fourmile (1992: 287) who claimed that a 
state tourism strategy produced by the National Centre for Tourism Studies in Travel and Tourism at James Cook University in Townsville failed to include an examination of the issue of Aboriginal involvement. This omission was particularly relevant given that the strategy was intended to set the direction for all future tourism activities in the state of Queensland. Thus, it would be reasonable to conclude from the policy catalogue, that both Liberal National Coalition and Labor federal and state governments appear to have paid minimal attention to policy content and formulation pertaining to ATSI tourism.

The diversity of policy authors revealed by the study reinforces the lack of continuity in policies containing reference to ATSI tourism over the 25-year period. Numerous government departments, including those of Tourism, Aboriginal Affairs, ATSIC, Multicultural Affairs, the Environment, Education, and Employment, have formulated policy relating to ATSI tourism. Although it is recognised that a change of departmental nomenclature is an accepted and regular occurrence in relation to a change in government, the policy catalogue identifies numerous and continually changing departments, with different functions, as being responsible for ATSI tourism policy. Such an approach may encourage inconsistent, rather than consistent policy formulation. Although not formally considered as part of the study due to lack of specific detail, an informal review of the policies revealed that there was a general failure to refer to preceding policies. A possible explanation for the finding of an ad hoc approach may be that governments have adopted a 'whole of government' approach to the development of ATSI tourism policy. This approach, suggested in A Framework for the Future and the Queensland Ecotourism Plan, might facilitate interaction and continuity between numerous government departments. However, the issue of ATSI tourism may well have simply been passed between government departments as a reactive rather than proactive response to developing ATSI tourism policy. The results of the policy catalogue support this proposition.

Concomitantly, the results identified that only a small amount of content $(2.7 \%)$ was allocated to ATSI tourism in 16 of the 17 policies analysed in the study. This factor, coupled with the previous data pertaining to ad hoc development and diversity of sources and authors, augments the concern of Hall et al. (1997) regarding an increasing uneasiness among tourism stakeholders about the effectiveness and the intended consequences of much government tourism policy. Furthermore, the results suggest that successive federal and state governments have adopted a reactive response to ATSI tourism. This may be the reason why diverse incompatible government objectives and a fragmented tourism industry had still not attended to issues pertaining to ATSI tourism raised 20 years previously (Altman, 1989).

In relation to the second objective of this study, the key findings were: (a) there were considerable overlaps and distinct interrelationships between environments; (b) to varying degrees, the economic environment has influenced the focus of policies pertaining to the social, political and ecological environments; and (c) ATSI tourism is increasingly being commodified into a saleable and marketable product and service.

The focus of the policies examined in this study reflected the social, economic, political and ecological environment. However, there were cases when the boundaries of these environments were indistinct. For example, some policies 
with a focus on the social environment (e.g. to decrease unemployment) had clear economic implications. Similarly, some policies with a focus on the ecological environment (e.g. conservation of the natural and cultural ATSI heritage) had distinct economic and social implications. The focus of the policies, such as those pertaining to cultural heritage and/or land rights, aligned with two or more environments and the study concluded that the boundaries of the broader environments were indistinct and were strongly influenced by the economic environment. More importantly, the study demonstrates that overall, the focus of the policies identifies a shift from the social environment to concerns relating to the economic environment.

This result has wide-ranging implications as Altman $(1989,1993)$, Altman and Finlayson (1992) and Martin (1995) believed economic opportunities to be less compatible with Aboriginal lifestyles and work aspirations than was first thought. This suggests that the strong emphasis placed by ATSI people on sociality and the maintenance of social relations should be a major consideration in policy development. However, this study found the focus of policies identified within the social environment relating to self-determination, remedying social disadvantage and land rights were recorded with a frequency of only 16 (from a total of 193). Meanwhile, Altman (1989) and Martin (1995) believed the problem pertaining to policy development is compounded by the fact that social capital far outweighs the importance of financial or resource capital in ATSI culture. If the interpretations of these authors are correct, then, arguably, the focus of the policies pertaining to ATSI tourism has been misdirected and, if so, could be seen as irrelevant by the people for whom the policies were designed.

The pervasiveness of the economic environment throughout the 17 policies is highlighted in the results of the study which reveal the focus of policies emanating from the economic environment were recorded with a frequency of 93 (from a total of 193). This result is supported by Finlayson (1993), who proposed that government focus on economic success, as an evaluative measure, needed adjustment to deal with social factors. For instance, although Aboriginal landowners participating in tourism in rural and urban Australia may be missing out on a degree of economic opportunity in the tourism industry, for many ATSI people success is not likely to be measured totally, or perhaps even partially, in financial terms. Rather, success may be evaluated by changes that improve the socio-economic quality of life for the whole community, with better service delivery or in the realisation of wider aspirations. Furthermore, it is questionable as to the degree to which Aboriginal tourism can increase the economic position of ATSI people (Altman, 1989, 1993; Altman \& Finlayson, 1992; Martin, 1995). A capitalist economy presupposes that all are able to compete on equal terms (Manning, 1976). However, many ATSI tourism ventures are small scale (Stimpson et al., 1996) and 'significant capital resources are needed to establish tourism enterprises and this is a major hurdle for poor people' (Altman, 1989: 471). Moreover, 'those entering a competitive market with a few goods have little bargaining power, and at the close of business are most unlikely to find they have not improved their relative position in any way' (Schott, 1987: 46).

Reflected in 16 (94\%) of the policies was the issue of increasing ATSI employment. Taylor and Hunter (1997) examined issues regarding the position of indigenous people in the Australian labour market. They maintained that fiscal 
tightening in the last 10 years threatened the opportunities of public sector employment for indigenous people and suggested looking to the private sector to counteract the problem. The authors believed that tourism could provide potential private sector employment to indigenous people, but identified several barriers that must be overcome to meet market conditions and to increase private sector employment. These barriers to successful ATSI tourism enterprises were seen as a lack of funds for infrastructure and services, a lack of information pertaining to tourism and tourists and a cultural gulf between host and tourist. Furthermore, PATA (1990) and Taylor and Hunter (1997) identified a lack of management and operational skills, preventing the confident planning and management of tourism ventures. This is supported by the findings of the study, which revealed eight (47\%) of the focus of policies reflected the need to increase ATSI education to enhance employment opportunities.

The focus of policies concerning the utilisation and marketing of the natural and cultural heritage of ATSI people aligned with the economic environment, also appeared in 16 (94\%) of the ATSI tourism policies. For example, The Report of the Committee of Aboriginal Employment and Training Programs (Commonwealth Department of Employment, and Industrial Relations \& Department of Aboriginal Affairs, 1985: 318) claimed that government and industry policy objectives regarded Aboriginal involvement in tourism only as 'picturesque subject matter for advertising'. Again in 1991, the Chairman of the Aboriginal Arts Committee for the Australia Council, Lin Onus stated, 'it is not uncommon these days to see (ATSI) art or culture used as a sales aid for anything and everything' (Reconciliation \& Social Justice Library, 1999b: 2). Nine (52\%) of the focus of policies related to the promotion of Australian tourism and the Office of National Tourism (1999: 1) clearly states that 'Even for those for whom indigenous culture is not a special interest, the further development of indigenous tourism will increase the range of experiences available ... as well as to promote Australia as a must see destination'.

Hence, the degree of influence the economic environment exerts on the focus of ATSI tourism policy might reflect a concerted effort by policymakers to capture a share of the increasing international demand for the indigenous tourism market, principally by commodifying ATSI tourism. The spread of tourism into formerly ignored areas, which are home to indigenous populations, often results from a combination of factors including an increase in interest in marketing things natural or unspoiled (Butler \& Hinch, 1996). However, indigenous societies are often 'showcased' for economic purposes and culture is viewed as a commodity that can be packaged for the tourist (Robinson, 1999). The results of this study reveal that the utilisation of ATSI culture as a marketing tool was one of the most frequently identified foci of policies, appearing 16 (94\%) times.

There appears to be two schools of thought on the commodification of ATSI culture. On the one hand, a report from the Reconciliation and Social Justice Library (1999b: 1) claims 'the current trend in ATSI communities to commodify culture for the commercial market is in tourism, and the large scale marketing of souvenirs and clothing objects, by a small number of companies, such as Balarinji and Desert Designs.' Furthermore, the economic advantages which result from commercial relationships based on commodifying aspects of indigenous social and cultural life 'offer more than a fistful of dollars, they offer ATSI people 
opportunities for economic status, empowerment and dignity' (Reconciliation \& Social Justice Library, 1999b: 1). However, this advantage was dependent upon providing appropriate regulation and protection to indigenous cultural copyright. On the other hand, Kleiger (cited in Hollinshead, 1996) believes that ethnic, cultural or adventure tourism can turn exotic culture into commodities, and individuals into amusing objects for tourism consumption. Consequently, 'novel encounters become routine for both host and guest, and cultural presentations become more and more removed from the reality of everyday life' (Kleiger cited in Hollinshead, 1996:313).

As authors continue to debate the positive or negative effects of the commodification of ATSI tourism, the results of this research suggest that such commodification might be due to the influence of the economic environment on policy foci relevant to the social, political and ecological environments. This economic influence may be stemming from a change in government attitudes towards traditional party ideologies. The third objective of the study addresses this statement.

Maddox (1991) claimed that Australian society should be enriched by the diverse attitudes of Australian governments' toward their roles, and their differing conceptions of what Australian society should be like. While all Australian parties embrace democratic ideals, albeit with a different balance of liberty, equality and fraternity, they are motivated more by electoral advantage (Maddox, 1991). Furthermore, Maddox cynically stated that Australian politics has witnessed convergent tendencies on both sides imposed by the necessities of electoral politics. Castles (1988: 3) took a more idealistic stance, believing the 'broad parameters that mark out the policy content of Australian democracy have much in common with those of other capitalist democracies because they are shaped by the democratic dialectic of the search for social protection in a capitalist economy.' Hanson (1998), on the other hand, was noted as having accused the Liberal and Labor parties of being disciples of economic rationalism, worshipping the ideology from the same bed, and adopting policies designed purely to facilitate the growth of global capitalist multinational development.

Therefore, the issue arises as to whether the cynicism of Maddox (1991), the idealism of Castles (1988) or the scepticism of Hanson (1998) is more appropriate as a description of the approach adopted by successive Australian government ATSI tourism policies. Do, in fact, policies developed by various governments for ATSI tourism reflect the ideological underpinnings of the political party of the day or are they more pragmatic responses to shifting agendas in the game of politics (Coombe et al., 1982)?

Overall, the study revealed that most ATSI tourism policies are broadly indicative of their government authors' primary political ideologies. However, there are indeed identifiable inconsistencies in the ideological principles within the content of each policy. In other words, most policies contained a mix of political ideologies. Parties of both political persuasions exemplify this finding. For example, many of the ideological characteristics within Labor government policies were recognisable under the label of social democratism. The content within all Labor government policies espoused the continuation and promulgation of interventionist government, community involvement, government funding and the protection of community, environment and culture. However, evidence of the Labor government's use of the ideologies of economic rationalism and to a 
lesser extent laissez-faire capitalism are evident within the content of their policies; an example of this being the Queensland Aboriginal and Torres Strait Islander Economic Development Strategy, in which self-sufficiency for ATSI is promoted along with the desire to create a business climate to promote excellence in tourism. Moreover, the goals of minimal spending and streamlining and co-ordinating financial management are noted. The economic emphasis in the policy is extended to the goal of creating a marketable and profitable product and service to position Queensland and the Australian tourism industry as a competitive player in the world market.

Two scenarios could explain this approach within these policies. First, Altman's (1989) contention that indigenous Australians may prefer welfare assistance to economic self-sufficiency. Consequently, Labor governments may have responded to charges of facilitating a welfare dependent mind set, a criticism that has been broadly aimed at the reliance on the single ideology of social democratism. While social spending in a social democracy may provide more equitable opportunities for ventures such as the development of indigenous tourism, it may also create problems with regard to welfare dependency and result in a lack of individual responsibility. Secondly, that the strong right-wing faction of the Labor Party has overshadowed the more socially idealistic left and has become more in tune with the Liberal Party philosophy than with its own party platform. Labor governments may have learnt to adopt a 'corporate philosophy from the private sector' (Castles, 1988), which appears to have been initiated by the Hawke Federal Labor Government. Hawke's federal government was accused of adopting corporatist tendencies in its approach to economic management, and many believed it tempered 'its reformist blade into a dull metalic mirror of its opponents traditional policies' (Maddox, 1991: 281).

Conversely, the results reveal the political ideologies underpinning the Liberal National Coalition policies, such as The Final Report of the House of Representatives Select Committee on Tourism, appear to be broadly consistent with a conservative laissez-faire ideology which encourages individuals towards selfsufficiency in the belief that all citizens can achieve their desired goals through hard work, determination and perseverance. However, Liberal National Coalition policies also demonstrated a combination of ideologies similar to Labor.

Forell (1994) maintained the Liberal Party is trying to adopt a more humanitarian perspective. Perhaps then, the Liberal Party approach to policies such as $A$ Framework for the Future was undertaken to appease the idealistic goals of the conservative right via a paternalistic approach to indigenous tourism. Although social democratic ideology was represented in policies initiated by the Liberal National Coalition governments, references to this ideology were found to be secondary to laissez-faire capitalism and economic rationalism. They were also rather weakly worded. For example, statements alluding to the elimination of exploitation of ATSI people and the provision of equal opportunity such as 'ventures should enable ATSI people to have some say in the activities of the company' and ensure the 'creation of appropriate jobs for Aboriginals in the areas where they live' were indicative of the policies.

Common to both governments has been the focus of economic rationalism and the pursuit of profit (Marinova, 1997; Pusey, 1992) and central to this ideol- 
ogy is the priority given to the development of existing products and services where only small levels of funding will be required to create significant investment opportunities. The economic rationalist approach of the 17 policies is evident in the identification of obstacles preventing ATSI participation, such as inadequate capital and assets, lack of training and skills, lack of industry confidence and the identification of ATSI tourism as commercially fragile. Furthermore, some policies advocated the use of Aboriginal culture as part of the production process of attaining economic efficiency in private tourism enterprises. Consequently, subjected to an economic rationalist approach, ATSI tourism development and growth could be viewed as an extraneous hindrance by an economically rational government as ATSI tourism is not simply about dollars and cents. It involves a complex and diverse set of issues including the requirement for social, cultural and environmental benefits, and thus places economic rationalism and ATSI tourism in diametric opposition.

Liberal National Coalition governments have instigated conservative, economically oriented policies, influenced by the ideological assumptions of such scholars as Ayn Rand (1961) and Adam Smith (cited in Sherman, 1987). Labor Party policy is formulated along the lines of socialist doctrine and the ideological assumptions of liberal thinkers such as Hobbes (cited in Sherman, 1987). However, from the 1970s onwards, it has become increasingly difficult to differentiate the ideology underpinning the policy of the two opposing political parties. Interestingly, while the public rhetoric used by both parties would imply that they are ideologically different (Maddox, 1991), the results indicated that in regard to policy relevant to ATSI tourism, they appear to share more in common than is acknowledged. This suggestion is further corroborated by the predominance of the economic environment within the focus of all policies irrespective of their political source and authorship.

\section{Conclusion}

Governments not only create the environment in which the different stakeholders of indigenous tourism work but foster and facilitate the improvement of ATSI tourism enterprises (Schmiechen cited in Brownbill, 1997). The ultimate success of an ATSI tourism product, then, would appear to be largely dependent upon the policies of government. The results from the study of government ATSI tourism policy written between 1975 and 1999 have identified three major findings. These are: (a) a disparate publication record of ATSI tourism policy as a consequence of what might be characterised as governments' reactive approaches to ATSI tourism; (b) the strong influence of the economic environment on the focus of ATSI tourism policy, that has emphasised the commodification of the indigenous tourist product; and (c) the high priority given toward policy that is consistent with an economic rationalist ideology.

The catalogue of ATSI tourism policies suggests that successive governments have attempted to pacify those individuals and or groups voicing concern over a multitude of ATSI tourism issues through rhetoric within other policies. Thus, governments are provided with the opportunity to appease their conscience, in the justification that they have addressed the issues and are working on solutions. Moreover, the results suggest this disparate collection of policy pertaining 
to ATSI tourism may have come about due to a reactive response motivating the actions and intentions of successive Federal and state Liberal National Coalition governments and federal and state Labor governments. This assumption is supported by the paucity of ATSI tourism policy content, produced in what appears to be an ad hoc manner over the last 25 years.

The broader social, economic, political and ecological environments have influenced the focus of ATSI tourism policies. However, the degree to which these environments have influenced the focus of policies is shown to be less than that exerted by economic factors. These factors are represented by government concern with the development of a viable and competitive Australian tourism industry, assisted by the commodification of indigenous art and culture as manageable and tradable resources, alongside a lesser concern to increase the well being of ATSI people. In turn, this shift in policy focus might be attributed to a possible shift in political ideology by the major parties in Australia.

The ideology of economic rationalism was consistently identified throughout the analysis of the 17 ATSI tourism policies, and might well be the catalyst for what appears to be a disparate approach by government towards the commodification of ATSI tourism. Successive governments' adherence to the ideology of economic rationalism in these policies appears to prioritise economic development of the Australian tourism industry, at the possible expense of the social and ecological interests of ATSI people.

Finally, the predominance of the economic environment and the ideology of economic rationalism in ATSI tourism policies identified in the study raise the issue of whether this focus in the policies is appropriate. That is, the economic focus would appear to be diametrically opposed to stated social and environmental aspirations of ATSI people. While it has been acknowledged that indigenous people have a particular interest in the management and well-being of their environment (Recognition Rights and Reform, 1999: 1), the economic interests tend to judge the worth of a tourism project by the bottom line of the balance sheet rather than the well-being of people who contribute to the balance sheet. Thus, the results of this study indicate that if economic rationalism underpins further government ATSI tourism policy, then the future development of ATSI tourism may not be conducive to other goals and aspirations of ATSI people.

Whilst keeping in mind that the conclusions of this study emanated from an analysis of written policy documents, further research should investigate the experiences of the people who developed the policies. Such research would corroborate the results of this study, in addition to building further understanding of the policy development process as it relates to ATSI tourism.

\section{Notes}

1. This study was conducted by the primary author as an honours thesis at Griffith University.

2. Three policies became known to the authors after the conduct of the study. These were the National ATSI Rural Industry Strategy (ATSIC, 1997), the National ATSI Cultural Industry Strategy (ATSIC, 1997), and Queensland Cultural Tourism: A Framework for Development (The Arts Office and QTTC, 1996) and were not included in the analysis.

3. For the purpose of the study, 'Liberal' is deemed to represent the coalition of the Liberal Party of Australia and the National Party of Australia, where the National 
Party is the junior partner in federal politics and the dominant partner in Queensland state politics.

\section{Correspondence}

Any correspondence should be directed to Michelle Whitford, School of Tourism and Leisure Management, University of Queensland, Ipswich 4305, Australia (m.whitford@mailbox.ug.edu.au).

\section{References}

Aboriginal Development Commission (1985) National Aboriginal Bicentennial Objectives. Canberra: Commonwealth of Australia.

Altman, J.C. (1989) Australian tourism and aborigines. In J.C. Altman (ed.) Aborigines, Tourism, and Development: The Northern Territory Experience. Northern Territory: North Australian Research Unit.

Altman, J.C. (1993) Indigenous Australians in the National Tourism Strategy: Impact, Sustainability and Policy Issues. Discussion paper no. 37. Canberra: Centre for Aboriginal Economic Research.

Altman, J.C. and Finlayson, J. (1992) Aborigines, Tourism and Sustainable Development. Discussion paper no. 26. Canberra: Centre for Aboriginal and Economic Research.

ATSIC and The Office of National Tourism (1995) Draft National Aboriginal and Torres Strait Islander Tourism Industry Strategy. Canberra: Commonwealth of Australia.

ATSIC and The Office of National Tourism (1997a) National Aboriginal and Torres Strait Islander Tourism Industry Strategy. Canberra: Commonwealth of Australia.

ATSIC and The Department of Primary Industries and Energy (1997b) National ATSI Rural Industry Strategy. Canberra: Commonwealth of Australia.

ATSIC (1997c) National ATSI Cultural Industry Strategy. Canberra: Commonwealth of Australia.

Brennan, F. (1992)Land Rights Queensland Style: The Strugglefor Aboriginal Self-management. Queensland: University of Queensland Press.

Brown, J. (1983) Tourism Gets Australia Going. Canberra: Australian Government Publishing Service.

Brownbill, S. (ed.) (1997) Proceedings of the Indigenous Economic Development Conference: Pathways to the Future Conference, Darwin. Canberra: Commonwealth Department of Employment, Education, Training and Youth Affairs.

Butler, R. and Hinch, T. (eds) (1996) Tourism and Indigenous Peoples. London: International Thomson Business Press.

Byrt, W.J. and Crean, F. (1972) Government and Politics in Australia. NSW: McGraw Hill.

Castles, F. (1988) Australian Public Policy and Economic Vulnerability. NSW: Allen and Unwin.

Callaghan, J. (1987) Fabian socialism, democracy and the state. In G. Duncan (ed.) Democracy and the Capitalist State. Melbourne: Cambridge University Press.

Craik, J. (1991a) Government Promotion of Tourism: The Role of the Queensland Tourist and Travel Corporation. Research paper no. 20. Brisbane: Griffith University.

Craik, J. (1991b) Resorting to Tourism: Cultural Policies for Tourist Development in Australia. Sydney: Allen and Unwin.

Commonwealth of Australia (1986) Report of the Australian Government Inquiry into Tourism. Canberra: Australian Government Publishing Service.

Commonwealth of Australia (1991) Royal Commission into Aboriginal Deaths in Custody. Canberra: Australian Government Publishing Service.

Commonwealth Department of Aboriginal Affairs (1989) Report of the Review Committee into the Aboriginal Arts and Crafts Industry. Canberra: Australian Government Publishing Service

Commonwealth Department of Aboriginal Affairs, Department of Employment, Education and Training, and Department of Employment Services and Youth Affairs (1987) Aboriginal Employment Development Policy. Canberra: Australian Government Publishing Service. 
Commonwealth Department of the Arts, Sport, the Environment, Tourism and Territories (1988) Directions for Tourism. Discussion paper. Canberra: Commonwealth of Australia.

Commonwealth Department of Communication and the Arts (1994)Creative Nation: Commonwealth Cultural Policy. Canberra: Commonwealth of Australia.

Commonwealth Department of Employment and Industrial Relations, and Department of Aboriginal Affairs (1985) Report of the Committee of Review of Aboriginal and Employment Training Programs. Canberra: Commonwealth of Australia.

Commonwealth Department of Sport, Recreation and Tourism (1986) Report of the Australian Government Inquiry into Tourism. Canberra: Australian Government Publishing Service.

Commonwealth Department of Tourism (1992) Tourism: Australia's Passport to Growth. A National Tourism Strategy (summary). Canberra: Commonwealth of Australia.

Commonwealth Department of Tourism (1993) Tourism: Australia's Passport to Growth. A National Tourism Strategy. Implementation Progress Report no. 1. Canberra: Commonwealth of Australia.

Commonwealth Department of Tourism (1994) National Ecotourism Strategy. Canberra: Commonwealth of Australia.

Commonwealth Department of Tourism (1995) Tourism: Australia's Passport to Growth. A National Tourism Strategy. Implementation Progress Report no. 2. Canberra: Commonwealth of Australia.

Coombe, D., Hartung, G. and Hawker, G. (1982) Platform for Government: The National Platforms and Policies of Australia's Political Parties Analysed and Compared. ACT: Yarralumla Soft.

Davidson, K. (1987) How the right gets its arithmetic wrong. In K. Coghill (ed.) The New Right's Australian Fantasy. Victoria: Penguin Books Australia.

Davis, G., Wanna, J., Warhurst, J. and Weller, P. (1993) Public Policy in Australia (2nd edn). St Leonards: Allen Unwin.

Department of Economic Development and Trade, and Department of Families, Youth and Community Care. (1998) Aboriginal and Torres Strait Islander Economic Development Strategy. Brisbane: Queensland Government.

Department of Tourism and Recreation (1973) Development of Tourism in Australia. Canberra: Australian Government Publishing Service.

Department of Tourism, Small Business and Industry (1997a) Framework for the Future. Brisbane: Queensland Government.

Department of Tourism, Small Business and Industry (1997b) Queensland Ecotourism Plan. Brisbane: Queensland Government

Department of Tourism, Sport and Youth (1995) Draft Queensland Ecotourism Plan. Brisbane: Queensland Government.

Dillon, M.C. (1987) Aborigines and Tourism in North Australia: Some Suggested Research Approaches. East Kimberley Working Paper no. 14. Australian National University, Canberra: Centre for Resource and Environmental Studies.

Ellis, B. (1998) First Abolish the Customer: 202 Arguments Against Economic Rationalism. Victoria: Penguin.

Finlayson, J. (1991) Australian Aborigines and Cultural Tourism: Case Studies of Aboriginal Involvement in the Tourist Industry. Working Papers on Multiculturalism no. 15. Wollongong: Office of Multicultural Affairs.

Finlayson, J. (1993) A critical overview of current policies and programs. In Indigenous Australians and Tourism: A Focus on Northern Australia. Proceedings of the Indigenous Australians and Tourism Conference. Darwin: ATSIC, Northern Territory Tourist Commission and the Office of Northern Development.

Forell, C.R. (1994) How We Are Governed: Federal State and Local Government. Australia: Longman.

Fourmile, H. (1992) Queenslands cultural tourism industry: The potential for Aboriginal and Torres Strait Islander involvement. In D. Coghlan, R. Craven and N. Parbury (eds) Aboriginal Studies: A National Priority (vol 2) (pp. 284-90). Enfield: Aboriginal Education Unit. 
Gadamer, H.G. (1976) The historicity of understanding. In P. Connerton (ed.) Critical Sociology, Selected Readings. Harmondsworth: Penguin.

Hall, C.M., Jenkins, J. and Kearsley, G. (eds) (1997) Tourism Planning and Policy in Australia and New Zealand: Cases, Issues and Practice. Sydney: Irwin Publishers.

Hanson, P. (1998) One Nation press release, http:/ / www.onenation.com.au / press.htm.

Hollinshead, K. (1996) The disidentification of Aboriginal life. In R. Butler and T. Hinch (eds) Tourism and Indigenous Peoples. London: International Thomson Business Press.

Industries Assistance Commission (1989) Travel and Tourism. Report no. 423. Canberra: Commonwealth of Australia.

Jenkins, W.I. (1978) Policy Analysis. London. Martin Robertson.

Kersbergen, K. (1995) Social Capitalism: A Study of Christian Democracy and the Welfare State. New York: Routledge.

Lucashenko, M. (1996) Policy and politics in the indigenous sphere: An introduction for bureaucrats. Aboriginal Politics and Public Sector Management, Research Paper no. 1. Brisbane: Centre for Australian Public Sector Management, Griffith University.

Maddox, G. (1991) Australian Democracy: In Theory and Practice. Melbourne: Longman Cheshire.

Manning, D.J. (1976) Liberalism. New York: St. Martin's Press.

Marinova, D. (1997) The little prince and economic rationalism. In M. Boothe and T. Hogan (eds) Ambivalence and Hope: Social Theory and Policy Making in a Globalising, Postmodern Australia. Western Australia: Murdoch University.

Martin, D.F. (1995) Money, Business and Culture: Issues for Aboriginal Economic Policy. Discussion Paper no. 101. Canberra: Centre for Aboriginal Economic Policy Research.

Miller, G. (1995) The future of ATSI tourism in Queensland. Interoffice memo, Brisbane: Queensland Tourist and Travel Corporation

Moore, J. and Herron, J. (1997) Joint statement: National framework for indigenous tourism, http:/ / www.dist.gov.au/media/archive/october97/298\%2D97.html.

Myers, M.D. (1995) Dialectical hermeneutics: A theoretical framework for the implementation of information systems. Information Systems Journal 5 (1), 51-70.

National Aboriginal and Torres Strait Islander Tourism Strategy (1994) Major Consultancy Report, Indooroopilly: National Centre for Studies in Travel and Tourism.

Native Title Act (1993) Canberra: Commonwealth of Australia.

Neuman, W.L. (1997) Social Research Methods: Qualitative and Quantitative Approaches. Boston: Allyn and Bacon.

Northern Territory Newsletter (1971) Aboriginal girls to be trained as tourist guides (March), 8.

Office of Multicultural Affairs in the Department of the Prime Minister and Cabinet (1993) Access and Equity Plan. Canberra: Australian Government Publishing Service.

Office of National Tourism (1998a) Aboriginal and Torres Strait Islander tourism: Tourism facts no. 11, http://www.dist.gov.au/tourism/FactsandFigures / abandtorrestourism.html.

Office of National Tourism (1998b) Talking Tourism 14. Canberra: Department of Industry, Science and Tourism.

Office of National Tourism (1999) About us: Aboriginal and Torres Strait Islander tourism. On www at http:/ / www.tourism.gov.au/FactsandFigures/abandtorrestourism.html.

Office of Northern Development (1993) Indigenous Australians and Tourism: A Focus on Northern Australia. Proceedings of the indigenous Australians and tourism conference. Darwin, Northern Territory: Aboriginal and Torres Strait Islander Commission, Northern Territory Tourist Commission and the Office of Northern Territory Development.

Parker, R.S. (1976) The meaning of responsible government. Politics 11 (2), 178-84.

Pacific Asian Travel Association (1990) Task Force Study. Cape York Peninsular: Tourism issues and opportunities. Singapore.

Patience, A. (ed.) (1985) The Bjelke Premiership 1968-1983: Issues in Public Policy. Melbourne: Longman Cheshire.

Pigram, J.J. (1993) Planning for tourism in rural areas: Bridging the implementation gap. 
In D.G. Pearce and R.W. Butler (eds) Tourism Research: Critiques and Challenges (pp. 15774). London: Routledge.

Pusey, M. (1991) Economic Rationalism in Canberra. A Nation Building State Changes its Mind. Victoria: Cambridge University Press.

Pusey, M. (1992) What's wrong with economic rationalism? In D. Horne (ed.) The Trouble with Economic Rationalism. Victoria: Scribe.

Queensland Government Statistics (1999) Aboriginal and Torres Strait Islander population in Queensland. On www at http://www.statistics.qld.gov.ua/hist_frameset.html.

Queensland Tourist and Travel Corporation (1999) Trends, http:/ /www.qttc.com.au/ qep/media02.htm.

Rand, A. (1961) For the new intellectual. New York: New American Library Inc. On www at http:/ / www.capitalism.org/capitalism/tour/index.html.

Rand, A. (1999) The capitalist site: Introducing objectivism. On www at http: / / www.capitalism.org/capitalism/tour/index.html

Reconciliation and Social Justice Library (1999a) Valuing cultures: Cultural tourism. On www at http://www.austlii.edu.au/au/special/rsjproject/rsjlibrary/car/kip3/ 12.html.

Reconciliation and Social Justice Library (1999b) Valuing cultures: The cultural dilemmas of involvement in the marketplace. On www at http://www/auslii.edu.au/au/ special/rsjproject/rsjlibrary/car/kip3/13.html.

Recognition, Rights and Reforms (1999) Realism, not good intentions. On www at http:/ / www.atsic.gov.au/issues/social_justice/recognit/58.gtm.

Robinson, M. (1999) Collaboration and cultural consent: Refocusing sustainable tourism. Journal of Sustainable Tourism 7 (3 and 4), 379-97.

Sawer, M. (ed.) (1982) Australia and the New Right. Sydney: Allen and Unwin.

Schott, K. (1987) The challenge to equity and fairness. In K. Coghill (ed.) The New Right's Australian Fantasy. Victoria: McPhee Gribble.

Sherman, H.J. (1987) Foundations of Radical Political Economy. New York: M.E. Sharpe.

South Australian Tourism Commission (1998) Indigenous Tourism Demand: A Background Research Report. Adelaide: South Australia Government.

Stimpson, R., Daly, M., Jenkins, O., Roberts, B. and Ross, S. (1996) Tourism in Australia: An Overview of Trends, Issues and Prospects. Occasional Paper no. 23. Canberra: Bureau of Tourism Research.

Strachan, G. (1998) The real free market economics. On www at http:/ / www.gwb.com. $\mathrm{au} / \mathrm{gwb} /$ news/ economic/280198.html.

Sturman, A. (1997) Social Justice in Education. Melbourne: Australian Council for Education Research.

Taylor, J. and Hunter, B. (1997) Promoting growth in indigenous employment: The role of the private sector, Australian Bulletin of Labour 23 (4).

The Arts Office and QTTC (1996) Queensland Cultural Tourism: A Framework for Development. Brisbane: The Arts Office and QTTC.

Zeppel, H. (1998a) Beyond the dreaming: Developing Aboriginal tourism in Australia. In Proceedings of New Zealand Tourism and Hospitality Research Conference: Advances in Research. Akaroa, New Zealand: Lincoln University.

Zeppel, H. (1998b)Selling the Dreamtime: Aboriginal culture in Australian tourism. In D. Rowe and G. Lawrence (eds) Tourism, Leisure and Sport: Critical Perspectives. NSW: Hodder Education.

Zeppel, H. (1999). Aboriginal Tourism in Australia: A Research Bibliography. CRC Tourism Research Report no 2, CRC Tourism. 